\title{
DENDROCHRONOLOGY OF TWO FOREST SPECIES IN THE URBAN AREA OF THE CITY OF PUERTO MALDONADO, PERU
}

\author{
Leif Armando Portal Cahuana ${ }^{1,2^{*}}$, Bertin Alexis Huamán Guevara ${ }^{1}$, Edwin Misael Mamani Luque ${ }^{1}$, Gilmara \\ Pires de Moura Palermo ${ }^{3}$, João Vicente de Figueiredo Latorraca ${ }^{3}$

\begin{abstract}
${ }^{1 *}$ Universidad Nacional Amazónica de Madre de Dios-UNAMAD, Departamento de Ingeniería Forestal y Medio Ambiente, Puerto Maldonado, Madre de Dios, Perú - *lportal@unamad.edu.pe; saposape30@hotmail.com; emamaniluque@gmail.com

${ }^{2}$ Universidade de São Paulo, Escola Superior de Agricultura "Luiz de Queiroz", Departamento de Recursos Florestais, Piracicaba, São Paulo, Brasil-1eifportal@usp.br

${ }^{3}$ Universidade Federal Rural do Rio de Janeiro-UFRRJ, Instituto de Floresta, Seropédica, Rio de Janiero, Brasil - gilpalermo@hotmail.com; latorraca@hotmail.com
\end{abstract}

Received for publication: 23/03/2020 - Accepted for publications: 02/07/2020

\begin{abstract}
Resumo
Dendrocronologia de duas espécies florestais na zona urbana da cidade de Puerto Maldonado, Peru. Utilizando métodos dendrocronológicos, avaliamos os anéis de crescimento dessas espécies e sua relação com o clima. As amostras de madeira foram coletadas com a sonda Pressler. As medições e análises dos anéis de crescimento das espécies foram realizadas usando técnicas padrão de dendrocronologia. A série mestre (cronologia), correlacionada com os índices climáticos (precipitação e temperatura), obtidos no banco de dados meteorológico NOAA. Os anéis de crescimento das espécies que crescem na área urbana são diferençados e anuais, delimitados pelo parênquima marginal e porosidade semicircular, além disso, C. alliodora apresenta áreas fibrosas. Ambas as espécies apresentaram uma correlação entre as árvores acima de 0.50. As idades máximas foram de 13 anos para C. allidora e 32 anos para C. fissilis. Da mesma forma, a baixa correlação entre o clima e as cronologias das espécies pode sugerir a influência de outros fatores ecológicos ou antropogênicos que interferem no crescimento dessas espécies. Finalmente, é demonstrado o potencial das espécies florestais para estudos dendrocronológicos na área urbana de Puerto Maldonado, Peru.

Palavras-chave: anéis de crescimento, crescimento radial, Cordia alliodora, Cedrela fissilis, Madre de Dios.
\end{abstract}

\begin{abstract}
We evaluated by dendrochronological methods the growth rings of these two species and their relationship with the climate. Wood samples were collected with the Pressler's probe. Measurements and analysis of the growth rings of the two species were performed using standard dendrochronology techniques. The master series (chronologies) were correlated with the climatic indices (precipitation and temperature), obtained from the NOAA meteorological database. The growth rings of the two species growing in the urban area are different and annual, delimited by the marginal parenchyma and semicircular porosity, in addition, C. alliodora presented fibrous areas. Both species presented an intercorrelation between the trees above 0.50. The maximum ages were 13 years for C. allidora and 32 years for $C$. fissilis. Likewise, the low correlation between the climate and the chronologies of the two species may suggest the influence of other ecological or anthropic factors that are intervening in the growth of these species. Finally, the potential of the two forest species for dendrochronological studies in the urban area of Puerto Maldonado Peru is demonstrated.

Keywords: growth rings, radial growth, Cordia alliodora, Cedrela fissilis, Madre de Dios.
\end{abstract}

\section{INTRODUCTION}

Many dendrochronology studies have been carried out in tropical forests since the verification of the growth rings annuity (COSTER, 1927). Progress has been developing and there are currently different forest species with robust chronologies. These studies in recent decades have been framed in three main themes 1) the reconstruction of the climate with long and robust chronologies and the relationship of climate with growth and further studies of stable isotopes. 2) the validation of growth patterns throughout life, improving the information of the permanent sample plots, and 3) the growth models that help forest management (BRIENEN et al., 2012; ROZENDAAL; ZUIDEMA, 2011). However, in recent years dendrochronological techniques have been used to relate the growth of forest species in urban areas, how these are having an impact on the local climate and also, to see the levels of urban pollution (PRETZSCH et al., 2017; VASCONCELLOS; TOMAZELLO; CALLADO, 2019) due to the concern of climate change worldwide. However, these studies are still scarce and for example in Peru not yet studied.

On the other hand, the department of Madre de Dios in the southeast of Peru, a forest region par excellence and also by Law 26311 declares it as the capital of Peru's biodiversity in 1994 to the present due to its different records biodiversity worlds. Within this reference, the capital of the department of Madre de Dios is the city of Puerto Maldonado, having native species growing naturally in its urban areas such as Cedrela fissilis Vell 
(Meliaceae), which is found in the flora included in Appendix III of the International Trade in Endangered Species of Fauna and Flora (in Spanish Comercio Internacional de Especies Amenazadas de Fauna y Flora (CITES)), together with $C$. odorata L. and $C$. angustifolia Sessé \& Moc. Ex DC. For this study, according to the inventory carried out in the city of Puerto Maldonado/La Joya sector, an example of 30 C. fissilis trees were taken, greater than 30 centimeters in diameter at chest height, considering that below this diameter, it can be estimated at least twice as many trees. At the same time, the species Cordia alliodora (Ruiz \& Pav.) Cham. grows naturally in the urban area of Puerto Maldonado, and together with $C$. fissilis, have shown potential for dendrochronological studies in tropical forests (BRICEÑO; RANGEL; BOGINO, 2016; PAREDES, LÓPEZ; NAVARRO, 2016; MARCON et al. 2019), mainly because they have good anatomical delimitations of their growth rings in the phenology as they are both deciduous species, showing cross-dating and correlations between the growth rings of the two species (STAHLE et al., 1999).

However, in these two study species in the urban area, it is not known: What are the ages of these trees? What are the relationships between local climate and growth? And if these species maintain the dendrochronological potential in the urban areas.

\section{MATERIALS AND METHODS}

\section{Study area}

The samples were collected in the La Joya sector, in the city of Puerto Maldonado, Madre de Dios regionPeru (Figure 01), where the $C$. alliodora and $C$. fissilis species are abundant and very common in the urban area. The city of Puerto Maldonado is located between the rivers of Tambopata and Madre de Dios, the tropical forests of the region are evergreen and characterized by a high exuberant and heterogeneous biodiversity (CHAVEZ et al., 2013). It is located at 250 meters above sea level, the soils are highly degraded by the high temperature and humidity, with the leaching of nutrients due to the high precipitation during part of the year. They are soils poor in nutrients and with a thin organic layer. The climate is warm and with abundant precipitation in all seasons of the year (Figure 01), which varies in an interval of 2000-4000 mm/year. The rainfall regime is variable throughout the year, and the season with the highest rainfall is between December and March (wet season); the average annual rainfall is $2000 \mathrm{~mm} /$ year. The monthly temperature varies from $24-26^{\circ} \mathrm{C}$, the maximum values reach an interval of $33-36{ }^{\circ} \mathrm{C}$ from August to September (BRAVO, 2013).

\section{Inventory of $C$. alliodora and $C$. fissilis trees}

After locating the research area, the trees were identified and selected, for which the species $C$. alliodora (Añayo caspi) and C. fissilis (Cedro) were inventoried. This inventory determined the population, sample, and map of the location of the trees, in the streets of the city of Puerto Maldonado, La Joya sector. The inventory was carried out in trees with a Diameter at Breast Height (DBH) greater than $10 \mathrm{~cm}$ for C. alliodora and $30 \mathrm{~cm} \mathrm{DBH}$ for $C$. fissilis.

The population of this investigation was the trees of $C$. alliodora and $C$. fissilis, which were inventoried in La Joya sector of the city of Puerto Maldonado. There were a total of 46 trees for C. alliodora and 30 trees for C. fissilis, with information on Universal Transverse Mercator (UTM) coordinates, total height, diameter, and type of crown. The samples were 07 trees of $C$. alliodora and 20 trees of $C$. fissilis (Figure 1), depending on the ease of collection. The sampling was of a simple random type, that is, the trees in the samples are chosen at random from the population, considering the phytosanitary aspect and the possibility of collection, etc. The distance between trees for the $C$. alliodora species was $0.01-1.09$ kilometers and for the $C$. fissilis species, from 0.031 to 2.09 kilometers. 

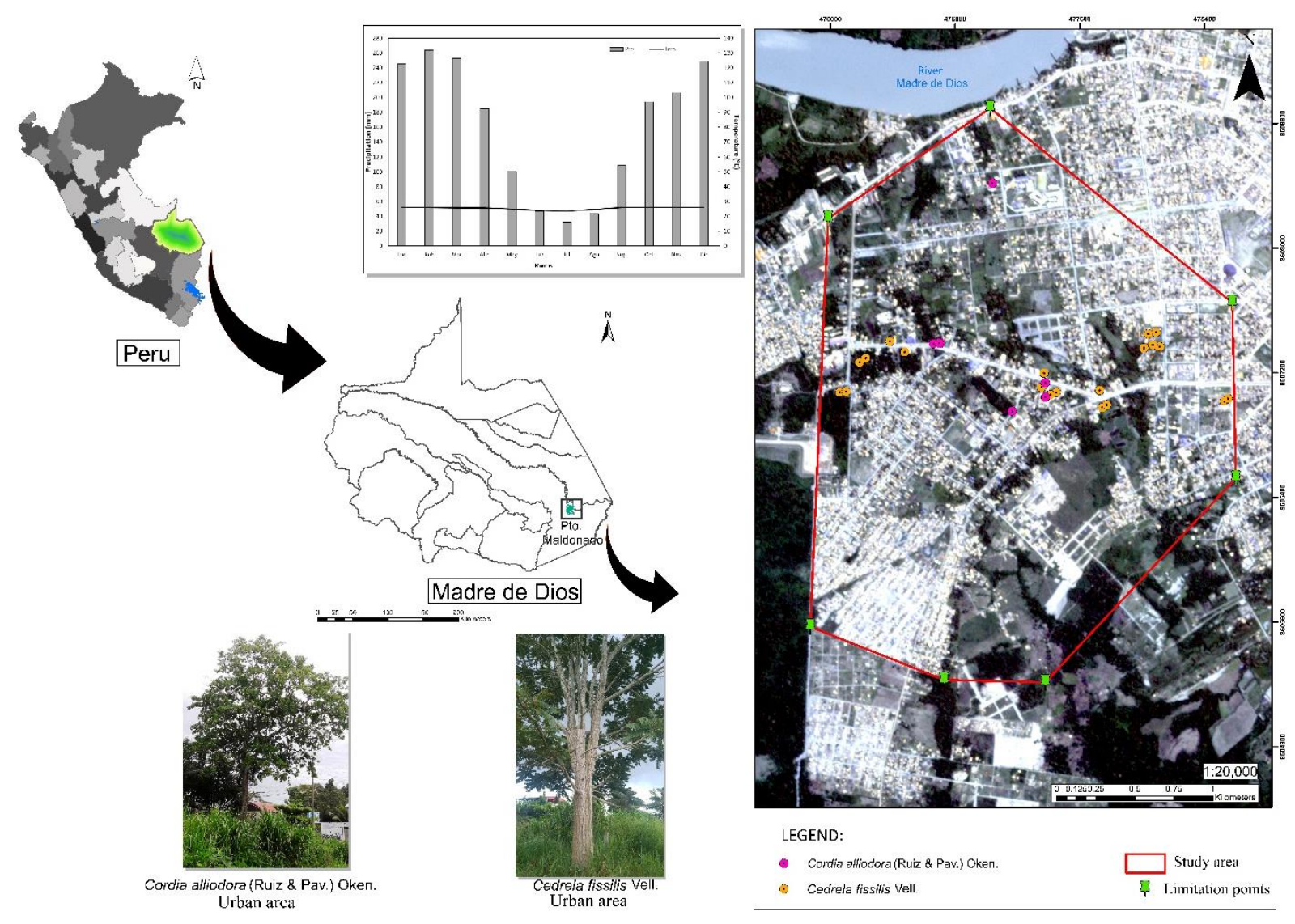

Figure 1. Map of Peru, showing the department of Madre de Dios with the urban area of the city of Puerto Maldonado and the location of the Cordia alliodora and Cedrela fissilis species. Climatic diagram of Madre de Dios with data from 1901 to 2017, showing the well-defined dry season.

Figura 1. Mapa do Peru, mostrando o departamento de Madre de Dios com a área urbana da cidade de Puerto Maldonado e a localização das espécies Cordia alliodora e Cedrela fissilis. Diagrama climático de Madre de Dios com dados de 1901 a 2017, mostrando a estação seca bem definida.

\section{Demarcation, Collection, and Extraction of the Samples}

Thus, 07 C. alliodora trees and the $20 \mathrm{C}$. fissilis trees were randomly selected and demarcated, from $\mathrm{La}$ Joya sector (Figure 01), considering the phytosanitary, straight stem and site aspects to avoid the edge effects as this influences the growth of the tree due to the accumulation of nutrients, wind, etc.

The wood samples of $C$. alliodora and $C$. fissilis trees were collected through the non-destructive method, with the help of the Pressler hole or Increment Probe, with dimensions of 5.1 x $400 \mathrm{~mm}$ (diameter x length). From each selected tree (07/20), four (04) radial samples were collected at chest height (cortex - medulla direction), which from now on we will call them "series". They were then packaged in large plastic straws and later coded for processing and analysis in the Wood Anatomy Laboratory of the Wood Technology Pilot Plant of the National Amazonian University of Madre de Dios.

\section{Preparation of wood samples}

The "series" wood samples obtained from the 07/20 trees were glued on a wooden support and adjusted with wick, considering important the cross-section looking up. The field codes were respected in each wooden support. Subsequently, the series were dried at room temperature, sanded and polished in a sequence of sandpaper of increasing granulation (80-1200 grain $\left./ \mathrm{cm}^{2}\right)$, so that the growth rings of C. alliodora and C. dissilis stand out in the cross-section of the series.

Identification, characterization of growth rings, digitization of samples and measurement of growth rings

It could be identified the growth rings of $C$. alliodora and Cedrela fissilis observing the cross-section with a 10x magnifying glass and with a Leica stereoscope microscope, marking the delimitation of each growth ring on the wooden support. The characterization of the growth rings of each species was based on the International Association of Wood Anatomists (IAWA) Committee (IAWA, 1989). 
Subsequently, the samples were digitized with a scanner at a resolution of 1200 dpi to highlight the rings and make their observation and subsequent measurement better. The digitized images of the trees were measured with the Software Image Pro Plus v 4.5, before this step, the scales were calibrated. After measuring the width of the growth rings manually, the values obtained for each tree were exported to Microsoft Office Excel to be sorted and subsequently analyzed.

\section{Synchronization of growth rings and elaboration of species chronology}

Crossdating, which consists of patterns of width between the rings and between the measured series of the same trees or between patterns of width of rings of different trees of $C$. alliodora and $C$. fissilis, to attribute a calendar year for each growth ring detected.

The data of the width of the growth rings were processed by the statistical program COFECHA version 6.00p (HOLMES, 1983), for the control and verification of the synchronization of the series between and within each tree, for C. allioroda in the period 2003-2015 and for C. fissilis in the period 1986-2017; The program also allows identifying the existence of false growth rings or missing rings for later control, in addition to allowing the synchronization of the series to be checked and corrected.

To obtain the chronologies of the species, in the La Joya sector, the ARSTAN software (MRWE Application Framework Copyright (C) 1997-2004) (HOLMES, 1983) was applied. The software allowed the standardization of the individual series of each tree, using a cubic spline of 10 years for C. alliodora and 30 years for C. fissilis.

\section{Radial growth}

This evaluation used 07/20 trees selected by species, determining the growth in diameter of the tree trunk from: 1) Annual Current Increase in Diameter (ACID); 2) Accumulated Diametrical Increase (ADI); 3) Average Annual Increase in Diameter (AAID).

$$
\begin{gathered}
\boldsymbol{C A I}=2 \times \text { Ring width } \\
\text { DIC }=\sum_{1}^{n} C A I
\end{gathered}
$$

After knowing the ACI for each year, the Average Annual Increase (AAI) for each year of growth was calculated, expressed as the sum of the current annual increase.

$$
\boldsymbol{M A I}=\frac{\sum C A I_{D B H}}{A g e}
$$

\section{Chronology and relationship with the local climate}

The chronologies of the species $C$. alliodora and $C$. fissilis were correlated with the monthly values of temperature and precipitation, obtained from the National Oceanic and Atmospheric Administration database (NCEP-NCAR Reanalysis); historical data of air temperature and total precipitation (KALNAY et al., 1996; NOAA, 2017). With these historical data of precipitation and temperature, it is compared with the previous year, current year, and later year, understanding that they are correlations made with the chronologies of each species.

\section{RESULTS}

\section{Characterization of the Growth Rings of the species}

The $C$. alliodora and $C$. fissilis species were characterized in their cross-section by presenting different growth rings to the naked eye (Figure 2). Both species presented the limit of the growth layers characterized by marginal parenchyma and semicircular porosity. C. alliodora also showed density variation that occurs due to the presence of fibrous areas, with radial flattening of the fibers and greater thickening of its walls, and a lower frequency of vessels, presenting a dark coloration. 


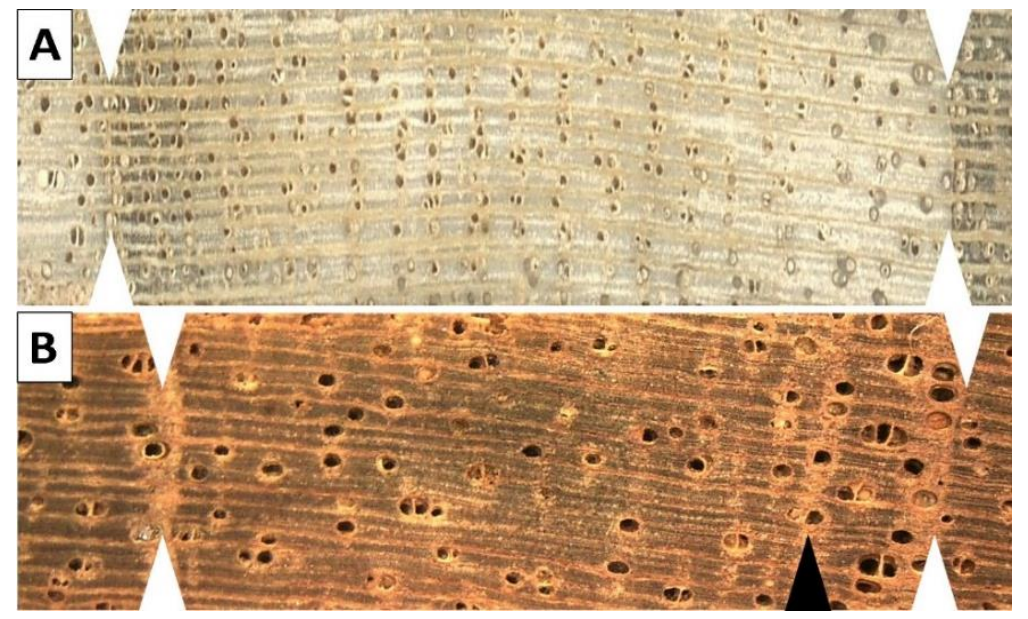

Figure 2. Macroscopic anatomy of the growth rings of species A) C. alliodora. B) C. fissilis, showing the typical marking of the limits of the growth rings of the species with white arrows and false rings with black arrows.

Figura 2. Anatomia macroscópica dos anéis de crescimento das espécies A) C. alliodora. B) C. fissilis, mostrando a marcação típica dos limites dos anéis de crescimento da espécie com setas brancas e anéis falsos com setas pretas.

\section{Dendrochronology of the species}

Through the analysis and interpretation of the growth ring width data performed by the COFECHA software, it could be synchronized the chronological series of the two species analyzed. The result of the intercorrelation for each species presented high values (Table 1), which allowed a good fit between the series of the growth rings of the individual trees.

Table 1. Quality control result of the measurements of the width of the growth rings of the species Cordia alliodora and Cedrela fissilis.

Tabela 1. Resultado do controle de qualidade das medidas da largura dos anéis de crescimento das espécies Cordia alliodora e Cedrela fissilis.

\begin{tabular}{lcc}
\multicolumn{1}{c}{ Parameter } & C. alliodora & C. fissilis \\
\hline $\begin{array}{l}\mathrm{N}^{\circ} \text { of trees and series before } \\
\text { quality control }\end{array}$ & $07(28)$ & $20(80)$ \\
$\mathrm{N}^{\circ}$ of trees and series after & $07(23)$ & $17(33)$ \\
quality control & 23 & 33 \\
Number of dated series & $2003-2015$ & $1986-2017$ \\
Master series (chronology) & 0.59 & 0.51 \\
Mean correlation & 0.48 & 0.47 \\
Mean sensitivity & 13 & 32 \\
\hline
\end{tabular}

For the chronologies produced, the Pearson intercorrelations were equal to 0.59-0.51. These values are highly significant $(p<0.01)$. The average sensitivity for the species was $0.48-0.47$. After the synchronization carried out by the COFECHA software, the ARSTAN software was applied to the data and the master chronologies of the growth rings were produced for the set of trees of the C. alliodora and $C$. fissilis species, in addition to the number of samples (series) used for the chronologies. The master series was 13 years (2003-2015) for C. alliodora and 32 (1986-2017) for C. fissilis. (Figure 3A). 

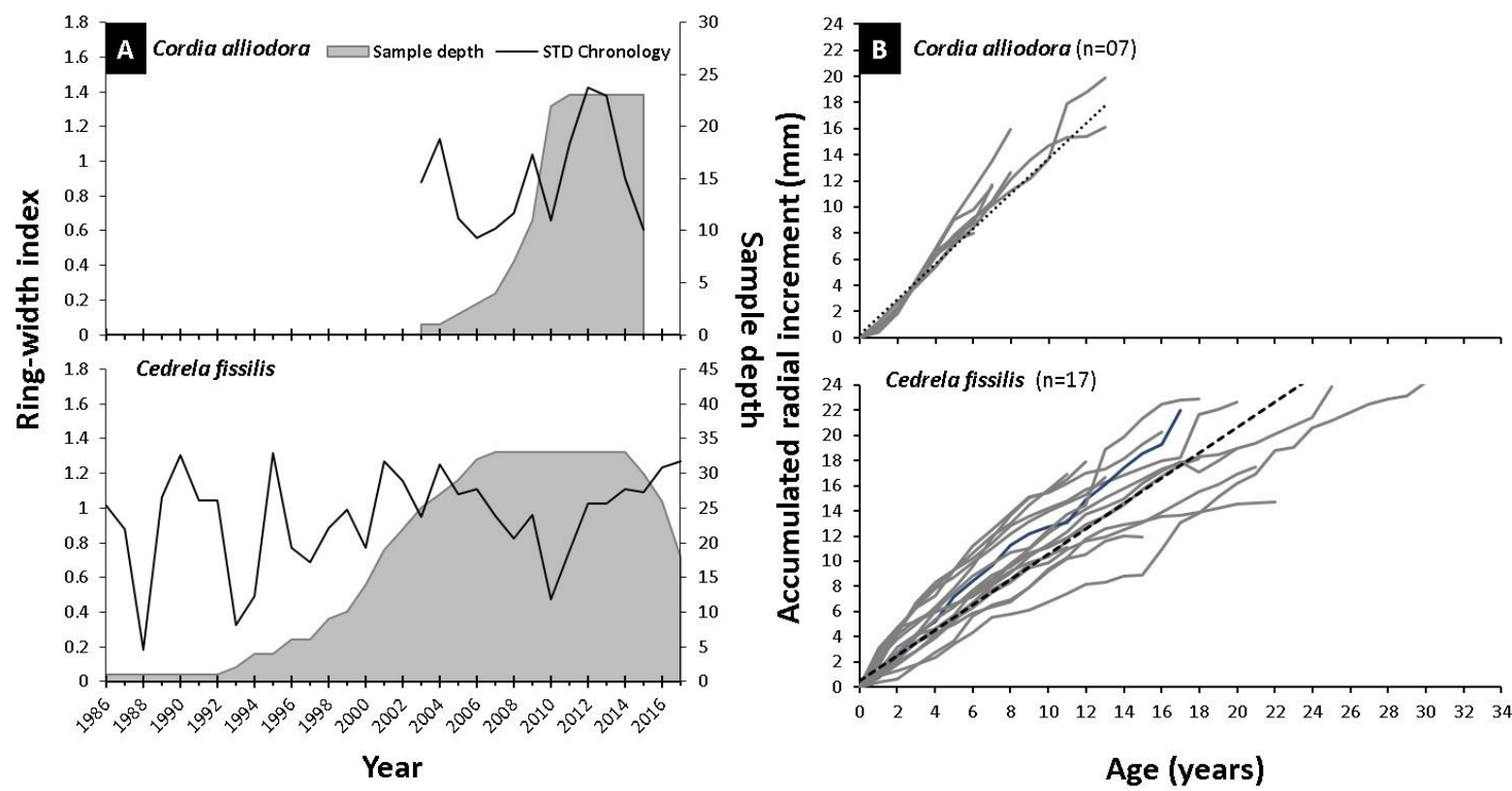

Figure 3. A) Master chronology and depth of samples for C. alliodora and C. fissilis species in the urban area of Puerto Maldonado. B) Cumulative radial increase of the C. alliodora and C. fissilis species in the urban area of Puerto Maldonado. The dashed lines represent the average values of the accumulated increase of the species.

Figura 3. A) Cronologia mestra e profundidade de amostras para as espécies C. alliodora e C. fissilis na área urbana de Puerto Maldonado. B) Aumento radial cumulativo das espécies C. alliodora e $C$. fissilis na área urbana de Puerto Maldonado. As linhas tracejadas representam os valores médios do aumento acumulado das espécies.

\section{Radial increase in species}

The C. alliodora and $C$. fissilis species showed a variation in the width of the growth rings. Variations in diameter at chest height of $C$. alliodora ranged from 12 to $48 \mathrm{~cm}$, and for $C$. fissilis, it was 23 to $58 \mathrm{~cm}$. These forest species growing in the urban area of Puerto Maldonado had the same growth pattern but these trees had different ages (Figure 3B). The annual current increase and the accumulated average increase for $C$. alliodora were $14.4 \mathrm{~mm} /$ year and $135.78 \mathrm{~mm} /$ year respectively. On the species C. fissilis, it was $10.6 \mathrm{~mm} /$ year and 170.28 $\mathrm{mm} /$ year respectively. It could be observed similar trends of the trajectories of the $C$. alliodora and $C$. fissilis, where approximately in the first five years they presented a similar growth and afterward they were differentiated with their growth, maintaining the average growth not so markedly.

\section{Climate-growth relationship}

In the case of the $C$. alliodora species, the previous year showed that at the end of the dry season (October) and the beginning of the rainy season (November) there were no significant negative correlations. In the case of the $C$. fissilis species, it could be observed that there is a positive correlation but not significant $(\mathrm{r}=0.34 ; p<0.05)$. In the current year, it could be noted that the $C$. fissilis species presented a significant and negative correlation in January with the precipitation. The two species presented a positive correlation at the beginning of the dry season, C. alliodora presenting a significant correlation in June $(\mathrm{r}=0.57 ; p<0.05)$. Finally, in the following year, only $C$. alliodora did have a positive correlation at the end of the rainy season, but it was not significant. In the case of the C. fissilis species, the positive correlation decreases from January to May, presenting a positive but not significant correlation (Figure 4). 


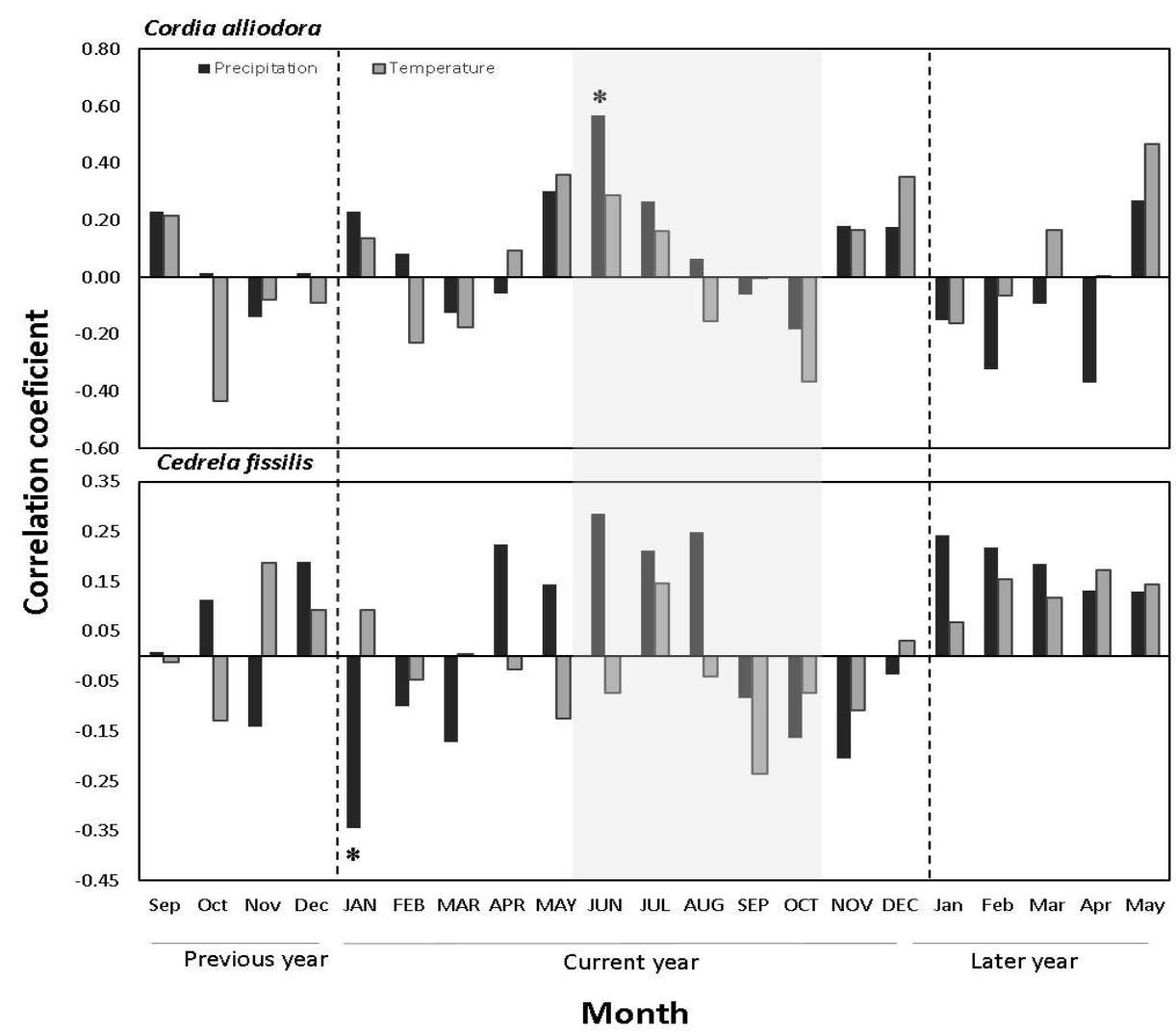

Figure 4. Climatic sensitivity of $C$. alliodora and $C$. fissilis chronologies to monthly precipitation and maximum monthly temperatures; $(*)$ denotes significance at 0.05 . The annual dry season is shaded.

Figura 4. Sensibilidade climática das cronologias de C. alliodora e C. fissilis à precipitação mensal e temperaturas máximas mensais; $\left(^{*}\right)$ indica significância em 0.05 . A estação seca anual é sombria. A estação seca anual é sombreada.

\section{DISCUSSION}

\section{Characterization of the Growth Rings of the species}

The characterization of the growth rings of C. alliodora at a macroscopic level in the urban area of Puerto Maldonado agrees with the scientific literature for this species (BRICEÑO; RANGEL; BOGINO, 2016; LEÓN, 2003). These descriptions also coincide with species of the same Cordia genus such as $C$. iguaguana (fibrous zone and semicircular porosity), C. saccellia (fibrous zone and marginal parenchyma), C. goeldiana (fibrous zone) (PEÑA et al., 2019) and they differ from the species C. apurensis, by presenting indistinct rings (WORBES, 1999).

Regarding the growth rings of the C. fissilis species in the urban area of Puerto Maldonado, various authors in a very similar way have described the marking of the growth rings of this species, mainly in natural forests, which are characterized by presenting the marginal parenchyma with semicircular porosity (large vessels lying in the marginal parenchyma) (MARCATI; ANGYALOSSY; EVERT, 2006; MARCON et al. 2019; PAREDES; LÓPEZ; NAVARRO, 2016; SCHÖNGART et al. 2017; TOMAZELLO; BOTOSSO; LISI, 2000). These macroscopic anatomical descriptions of growth rings are similar to other species of the genus Cedrela such as the species of $C$. odorata, with an extensive study on their growth rings (BRIENEN; ZUIDEMA; MARTÍNEZ, 2010; DÜNISCH; BAUCH; BRACAMONTE, 2002; WORBES, 1999). This marking of the marginal parenchyma growth rings with semicircular porosity also recorded in the species of the genus Cedrela such as C. kuelapensis, C. angustifolia, C. lilloi, C. montana, C. angustifolia (PAREDES; LÓPEZ; NAVARRO, 2016; PEÑA; SANTINI; TOMAZELLO, 2019; SCHÖNGART et al., 2017).

\section{Dendrochronology of the species}

The tropical species of C. alliodora and C. fissilis in urban areas of the city of Puerto Maldonado, La Joya sector, showed greater intercorrelations in the series, compared with dendrochronological studies in the last five years, with these species in natural forests of Colombia and Brazil. For C. alliodora in the tropical dry forest (Tolima), it could be found an intercorrelation of the series of 0.57 and in the urban area studied, this intercorrelation was 0.59 (BRICEÑO; RANGEL; BOGINO, 2016). This variation of the intercorrelation can be 
because the samples from Colombia are from a relic of tropical dry forest, and being a 70-year chronology. In the case of $C$. fissilis in a seasonal forest (Paraná), they found an intercorrelation of the series of 0.31 and in the urban area studied was 0.51 (MARCON et al., 2019). In the case of $C$. fissilis, the variation can be explained because the study in Brazil was in a Mixed Ombrophyllous Forests (MOF), with these trees having a chronology of 123 years. This result of a greater intercorrelation of the series in these two species in the urban area of Puerto Maldonado is possible because the trees studied are relatively younger than in the natural forest. A recent study of dendrochronology and dendroclimatology of Ceiba speciosa carried out in a contaminated urban area and in the Tinguá Biological Reserve in the state of Rio de Janeiro in Brazil, showed that the intercorrelation of the series in the forest and the urban area, in the species $C$. speciosa, the urban area presented a greater intercorrelation. This result was explained because in a natural forest the distance between the trees is smaller and the competition is greater and the competition in general from neighboring trees has a greater influence on their growth than in the climate variations (VASCONCELLOS; TOMAZELLO; CALLADO, 2019).

\section{Radial increase in species}

investigating C. alliodora in Colombia (Tolima) through regression models (Gompertz), they found that the growth in maximum diameter for the species is reached at 65 years with $205.5 \mathrm{~cm}$ in natural forest (BRICEÑO; RANGEL; BOGINO, 2016), showing an idea of growth for urban areas. On the other hand, a study of the C. fissilis species in two places in Chiquitano (Bolivia) found that in Concepción, the average annual growth was 2.07 $\mathrm{mm} /$ year and in Guarayos was $1.92 \mathrm{~mm} / \mathrm{year}$. These values are lower than in this investigation with $10.6 \mathrm{~mm} / \mathrm{year}$ (PAREDES; LÓPEZ; NAVARRO, 2016). Compared with a study with the Jacaranda copaia species in the same region, it showed that it had an average annual growth in an intervened forest of $8.0 \mathrm{~mm} /$ year lower than the results found in the present investigation (PORTAL et al., 2020). However, the results are similar to a study in Brazil comparing the growth of $C$. speciosa that they found that the trees in the urban area presented higher growth than in the forest (VASCONCELLOS; TOMAZELLO; CALLADO, 2019). As the trees did not have competition, they will present a lower height and will have a greater diameter, which will be expressed in their annual growth.

\section{Climate-growth relationship}

Although the studies that cover the influence of the climate on the growth and development of trees in urban areas in Peru are nil, it is necessary to start carrying out this kind of studies in more cities of Peru, to demonstrate the ecosystem services that involve trees in urban areas and their relationship with the local climate. The low positive and significant correlation between the climate (precipitation and temperature) and the chronologies of the two species studied (C. alliodora, C. fissilis) in the urban area of Puerto Maldonado may suggest the influence of other factors that are intervening in the growth of these species (VASCONCELLOS; TOMAZELLO; CALLADO, 2019), such as ecological and anthropic factors, in addition to nutrient availability, limitation of water uptake in urban areas and also much of this water is served or residual. Also, we need to know that these species have not been established in a planned system of urban ornamentation but have grown naturally in them, where their distance, growth, location, etc., are random.

A study carried out in 2017 shows that climate change in the world is showing a growth in the size of the tree, meaning that there is an increase in carbon sequestration, accelerating the expansion of the crown and roots of the trees and the provision of many ecosystem services. However, it also means faster aging of trees and what may generate the future need to replace it in urban areas. This study was carried out with dendrochronological techniques (PRETZSCH et al., 2017). Therefore, the $C$. alliodora and $C$. fissilis species could help us better understand these aspects of climate change that the city of Puerto Maldonado/La Joya sector has been experiencing, through specific studies with dendroclimatology.

\section{CONCLUSIONS}

- This research focused on the application of dendrochronological methodologies to obtain non-existent scientific information and helps to understand how $C$. alliodora and $C$. fissilis species are growing naturally in the urban area of Puerto Maldonado in Peru.

- In addition, the potential of the two forest species for dendroclimatic and dendrochemical studies is shown to relate them to urban pollution, climate, and chronology.

- We suggest that further research should focus on increasing potential species in urban areas for dendrochronology studies and also conduct comparative studies of growth and climate relationships in urban areas and native forest. 


\section{ACKNOWLEDGEMENTS}

To the National Amazonian University of Madre de Dios-UNAMAD, through the Vice-Rectorate for Research of UNAMAD. To the Programa Nacional de Becas y Crédito Educativo -PRONABEC (Beca Presidente de la República), for supporting the in postgraduate studies.

\section{REFERENCES}

BRAVO, S. Carretera Interoceánica Sur del Perú retos e innovación. CAF. p. 184, 2013. http://publicaciones.caf.com/media/34441/carretera_interoceanica.pdf.

BRICEÑO, A., J. RANGEL, Y S. BOGINO. Estudio de los anillos de crecimiento de Cordia alliodora (Ruiz \& Amp; Pav.) en Colombia. Colombia $\quad$ Forestal $19 \quad 12$ (2), 2016. https://doi.org/10.14483/udistrital.jour.colomb.for.2016.2.a07.

BRIENEN, R., G. HELLE, T. L. PONS, J.-L. GUYOT, Y M. GLOOR. Oxygen Isotopes in Tree Rings Are a Good Proxy for Amazon Precipitation and El Nino-Southern Oscillation Variability. Proceedings of the National Academy of Sciences 109 (42): 16957-62, 2012. https://doi.org/10.1073/pnas.1205977109.

BRIENEN, R., P. ZUIDEMA, Y M. MARTÍNEZ. Attaining the Canopy in Dry and Moist Tropical Forests: Strong Differences in Tree Growth Trajectories Reflect Variation in Growing Conditions. Oecologia 163 (2): 485-96, 2010. https://doi.org/10.1007/s00442-009-1540-5.

CHAVEZ, A., J. DÍAZ, R. FERNANDEZ, L. HUAMANI, Y R MORENO. Comparación de Áreas deforestadas a través de varias metodologías en la Provincia de Tahuamanu, Madre de Dios, Perú. En, 8. Foz do Iguaçu-Brasil. 2013. http://marte2.sid.inpe.br/col/dpi.inpe.br/marte2/2013/05.29.01.04/doc/p1607.pdf.

COSTER, C. Zur Anatomie und Physiologie der Zuwachszonen und Jahresbildung in den Tropen. I. Ann. Jard. Bot. Buitenzorg 37:49-160, 1927. https://edepot.wur.nl/162386.

DÜNISCH, O., J. BAUCH, Y L. BRACAMONTE. Formation of increment zones and intraannual growth dynamics in the xylem of Swietenia macrophylla, Carapa guianensis, and Cedrela odorata (meliaceae). IAWA Journal 23 (2): 101-19, 2002. https://doi.org/10.1163/22941932-90000292.

HOLMES, R. Computer-assisted quality control in tree-ring dating and measurement. Tree-ring bulletin, p. 11, 1983.

IAWA. IAWA list of microscopic features for hardwood identification. Vol. 10. IAWA Bull. 1989.

KALNAY, E., M. KANAMITSU, R. KISTLER, W. COLLINS, D. DEAVEN, L. GANDIN, M. IREDELL, et al. The NCEP/NCAR 40-Year Reanalysis Project. Bulletin of the American Meteorological Society 77 (3): 437-71, 1996. https://doi.org/10.1175/1520-0477(1996)077<0437:TNYRP>2.0.CO;2.

LEÓN, W. Anatomía de la madera de 9 especies del género Cordia L.(Boraginaceae-Cordioideae) que crecen en Venezuela. Revista Forest. Venez 47 (2): 83-94, 2003.

MARCATI, C. R., V. ANGYALOSSY, Y R. F. EVERT. Seasonal variation in wood formation of Cedrela fissilis (Meliaceae). IAWA Journal 27 (2): 199-211, 2006. https://doi.org/10.1163/22941932-90000149.

MARCON, A., T. LONGHI, FRANKLIN G., K. MARTINS, P. BOTOSSO, Y C. BLUM. Climatic Response of Cedrela Fissilis Radial Growth in the Ombrophilous Mixed Forest, Paraná, Brazil. Floresta e Ambiente 26 (3): e20180361, 2019. https://doi.org/10.1590/2179-8087.036118.

$\begin{array}{lllll}\text { NOAA. NOAA's Climate } & \text { Prediction } & \text { Center». } & 2017 .\end{array}$ http://origin.cpc.ncep.noaa.gov/products/analysis_monitoring/ensostuff/ONI_v5.php.

PAREDES, K., L. LÓPEZ, Y R. NAVARRO. Regional Chronologies of Cedrela fissilis and Cedrela angustifolia in Three Forest Types and Their Relation to Climate. Trees 30 (5): 1581-93, 2016. https://doi.org/10.1007/s00468016-1391-8.

PEÑA, J., L. SANTINI, Y M. TOMAZELLO. Wood Anatomy and Growth Rate of Seasonally Dry Tropical Forest Trees in the Marañón River Valley, Northern Peru. Dendrochronologia 55: 135-45, 2019. https://doi.org/10.1016/j.dendro.2019.04.008.

PORTAL, L. et al. Dendrocronología de Jacaranda copaia que contiene registro ENSO en Madre de Dios, Perú. Nativa, v. 8, n. 4, p. 572-578, 2020. https://doi.org/ 10.31413/nativa.v8i4.10082. 
PRETZSCH, H., P. BIBER, E. UHL, J. DAHLHAUSEN, G. SCHÜTZE, D. PERKINS, T. RÖTZER, et al. Climate Change Accelerates Growth of Urban Trees in Metropolises Worldwide. Scientific Reports 7 (1): $15403,2017$. https://doi.org/10.1038/s41598-017-14831-w.

ROZENDAAL, D.M., Y P.A ZUIDEMA. Dendroecology in the Tropics: A Review. Trees 25 (1): 3-16, 2011. https://doi.org/10.1007/s00468-010-0480-3.

SCHÖNGART, J., A. BRÄUNING, A. BARBOSA, C. LISI, Y J DE OLIVEIRA. Dendroecological Studies in the Neotropics: History, Status and Future Challenges. En Dendroecology, editado por M. Amoroso, L. Daniels, P. Baker, y J. Camarero, 231:35-73. Cham: Springer International Publishing. https://doi.org/10.1007/978-3-319-61669-8_3. 2017.

STAHLE, D.W, P.T MUSHOVE, M.K CLEAVELAND, F ROIG, Y G.A HAYNES. Management Implications of Annual Growth Rings in Pterocarpus Angolensis from Zimbabwe. Forest Ecology and Management 124 (23): 217-29, 1999. https://doi.org/10.1016/S0378-1127(99)00075-4.

TOMAZELlO, M., P. BOTOSSO, Y C. LISI. Potencialidade da familia Meliaceae para dendrocronologia em regiões tropicais e subtropicais. En Dendrocronología en América Latina, 52. Argentina: EDIUNC. 2000.

VASCONCELLOS, T., M. TOMAZELLO, Y CÁTIA HENRIQUES CALLADO. Dendrochronology and Dendroclimatology of Ceiba Speciosa (A. St.-Hil.) Ravenna (Malvaceae) Exposed to Urban Pollution in Rio de Janeiro City, Brazil. Dendrochronologia 53: 104-13, 2019. https://doi.org/10.1016/j.dendro.2018.12.004.

WORBES, M. Annual Growth Rings, Rainfall-Dependent Growth and Long-Term Growth Patterns of Tropical Trees from the Caparo Forest Reserve in Venezuela. Journal of Ecology 87 (3): 391-403, https://doi.org/10.1046/j.1365-2745.1999.00361.x. 